Seppo Rekolainen, Matti Verta \& Olli Järvinen: Mercury in snow cover and rainfall in Finland 1983-1984

Tiivistelmä: Sadeveden ja lumen elohopeapitoisuus Suomessa 1983-1984

Seppo Rekolainen, Matti Verta \& Anita Liehu: The effect of airborne mercury and peatland drainage on sediment mercury contents in some Finnish forest lakes Tiivistelmä: IImalevintäisen elohopean ja metsäojituksen vaikutus sedimentin elohopeapitoisuuteen eräissä Suomen metsäjärvissä

Matti Verta, Seppo Rekolainen, Jaakko Mannio \& Kari Surma-Aho: The origin and level of mercury in Finnish forest lakes

Tiivistelmä: Elohopean alkuperä ja pitoisuustaso Suomen metsäjärvissä

Jaakko Mannio, Matti Verta, Pirkko Kortelainen \& Seppo Rekolainen: The effect of water quality on the mercury concentration of northern pike (Esox lucius, L.) in Finnish forest lakes and reservoirs

Tiivistelmä: Veden laadun vaikutus hauen elohopeapitoisuuteen Suomen metsäjärvissä ja tekoaltaissa

Matti Verta, Seppo Rekolainen \& Kari Kinnunen: Causes of increased fish mercury levels in Finnish reservoirs

Tiivistelmä: Kohonneiden elohopeapitoisuuksien syyt Suomen tekoaltaissa

Kari Surma-Aho, Jaakko Paasivirta, Seppo Rekolainen \& Matti Verta: Organic and inorganic mercury in the food chain of some lakes and reservoirs in Finland Tiivistelmä: Orgaaninen ja epäorgaaninen elohopea eräiden Suomen järvien ja tekoaltaiden ravintoketjuissa

Jari Leskinen, Ossi V. Lindqvist, Jari Lehto \& Pekka Koivistoinen: Selenium and mercury contents in northern pike (Esox lucius, L.) of Finnish man-made and natural lakes Tiivistelmä: Seleenin ja elohopean pitoisuus Suomen tekoaltaiden ja luonnonjärvien hauissa 72

Vappu Pennanen, Pirkko Kortelainen \& Jaakko Mannio: Comparative study on the estimation of humic matter in natural waters

Tiivistelmä: Luonnonvesien humuspitoisuuden arviointi eri menetelmillä

Pirkko Kortelainen, Jaakko Mannio \& Vappu Pennanen: Characteristics of the allochthonous organic matter in Finnish forest lakes and reservoirs

Tiivistelmä: Alloktonisen orgaanisen aineen ominaisuuksista suomalaisissa metsäjärvissä ja tekoaltaissa

Tom Frisk \& Vappu Pennanen: A steady-state model for two humic fractions Tiivistelmä: Kahden humusfraktion tasapainotilan pagfif 
Tekijät ovat vastuussa julkaisun sisällöstä, eikä siihen voida vedota vesihallituksen virallisena kannanottona.

The authors are responsible for the contents of the publication.

It may not be referred to as the official view or policy of the National Board of Waters.

ISBN 951-46-9381-7

ISSN 0355-0982

Helsinki 1986. Valtion painatuskeskus 


\title{
ORGANIC AND INORGANIC MERCURY IN THE FOOD CHAIN OF SOME LAKES AND RESERVOIRS IN FINLAND
}

\author{
Kari Surma-Aho' ${ }^{1}$, Jaakko Paasivirta ${ }^{1}$, \\ Seppo Rekolainen 2) \& Matti Verta ${ }^{2}$ )
}

\begin{abstract}
SURMA-AHO, K., PAASIVIRTA, J., REKOLAINEN, S. \& VERTA,M, 1986. Organic and inorganic mercury in the food chain of some lakes and reservoirs in Finland. Publications of the Water Research Institute, National Board of Waters, Finland, No. 65.
\end{abstract}

\begin{abstract}
Contents of organic and inorganic mercury in food chain specimens, as well as sedimentation in two natural Finnish lakes and three impounded reservoirs, were studied. The proportion of organic mercury of total mercury varied in individual specimens from 32.7 to $100 \%$. Sedimentation (settleable solid) with very high contents of organic matter had ratios of organic to total mercury ranging from 2.4 to $87.3 \%$. These variations were similar in each of five water ecosystems studied. Benthic invertebrates had higher ratios of organic to total mercury than reported earlier. Total mercury concentrations in fish, zoobenthos and zooplankton of young impounded reservoirs were significantly higher than those of natural lakes. To explain this it is suggested that humic materials transfer mercury to the water and thence into the food chain.
\end{abstract}

Index words: Impounded reservoir, methyl mercury, total mercury, settleable solids, sedimentation, zooplankton, zoobenthos, fish, aquatic birds.

\section{INTRODUCTION}

Very recently a new environmental contamination problem has arisen, namely high concentrations of mercury in fish in young reservoirs. This phenomenon was first observed in the USA and Canada (Potter et al. 1975, Abernathy and Cumbie 1977, Cox et al. 1979, Meister et al. 1979, Bodaly and Hecky 1979) and soon also in Finland (Verta 1981, Lodenius et al. 1981, Alfthan et al. 1983). Lately, high mercury levels have also been found in fish in natural, unpolluted lakes with humic brown water (Hultberg and Hasselrot 1981, Björklund 1982, Paasivirta et al. 1983, Verta et al. 1986a). It was suggested

1) Department of Chemistry, University of Jyväskylä, Kyllikinkatu 1-3, SF-40100, Jyväskylä, Finland. for fish in reservoirs that the higher the concentration of organic material in the water, the higher is the accumulation of mercury through the gills (Alfthan et al. 1983). People eating fish from young reservoirs had elevated mercury concentrations in their hair (Lodenius et al. 1981, Alfthan et al. 1983). Organic mercury in fish tissues is almost entirely in the form of monomethyl mercury (Huckabee et al. 1979), which is a very hazardous substance for all living things.

The percentage ratio of organic mercury to total mercury is generally very high in fish (Noren and Westöö 1967) but lower in benthic invertebrates (Jernelöv and Lann 1971). The variation of this ratio in zoobenthos between

2) National Board of Waters, P.O. Box 250, SF-00101 Helsinki, Finland. 
areas, species and individuals has been reported to be very great (Huckabee and Hildenbrand 1974, Cox et al. 1975, Hildenbrand et al. 1976, Trudel et al. 1977).

The goal of this study was to monitor the enrichment of mercury in food chain of reservoirs and natural lakes by analysing inorganic and organic mercury concentrations in food chain specimens from these areas. This study is part of a wider program, "The cycle of mercury in water environments", coordinated by the National Board of Waters and executed in the Water Research Institute of the National Board of Waters and in the universities of Jyväskylä, Helsinki and Kuopio.

\section{MATERIALS AND METHODS 2.1 The study areas}

The lakes and reservoirs sampled are illustrated in Figure 1. Pihlajavesi (L1) and Seinäjärvi (L2) are natural lakes. Kalajärvi (R1) is a reservoir filled in 1977, while Kyrkösjärvi (R2) was filled in 1981 and Porttipahta (R3) in 1970.

$\mathrm{L} 2, \mathrm{R} 1$ and $\mathrm{R} 2$ are situated in the same river basin. General and water quality characteristics of the lakes and reservoirs are presented in Table 1.

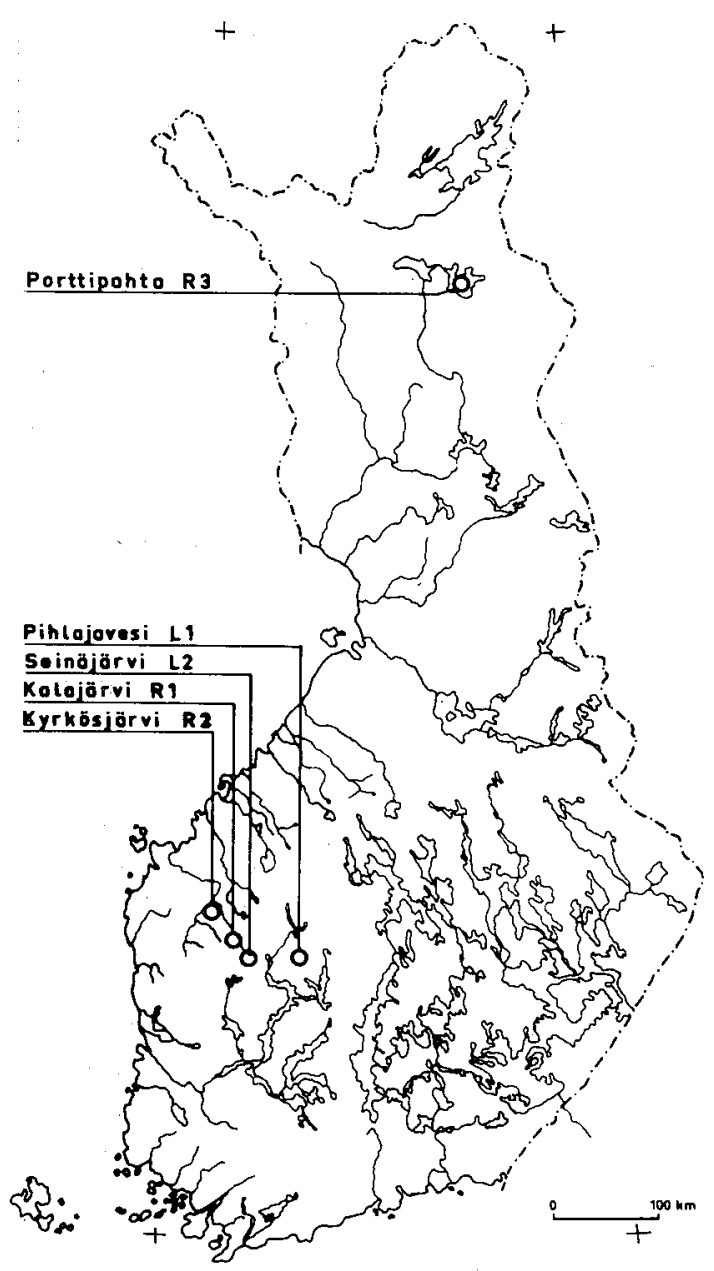

Fig. 1. The study areas.

Table 1. General and water quality characteristics of the study lakes $(L 1, L 2)$ and reservoirs $(R 1-R 3)$.

\begin{tabular}{|c|c|c|c|c|c|}
\hline Parameter & $\begin{array}{l}\text { L1 Pihlaja- } \\
\text { vesi }\end{array}$ & $\begin{array}{l}\text { L2 Seinä- } \\
\text { järvi }\end{array}$ & $\begin{array}{c}\text { R1 Kala- } \\
\text { järvi }\end{array}$ & $\begin{array}{c}\text { R2 Kyrkös- } \\
\text { järvi }\end{array}$ & $\begin{array}{l}\text { R3 Portti- } \\
\text { pahta }\end{array}$ \\
\hline Year of filling & - & - & 1977 & 1981 & 1970 \\
\hline Area km ${ }^{2}$ & 19.9 & 8.5 & 11.3 & 6.4 & 214 \\
\hline Volume $\mathrm{Mm}^{3}$ & 103 & 11 & 43 & 16 & 1350 \\
\hline Drainage area $\mathrm{km}^{2}$ & 370 & 97 & 500 & 820 & 2460 \\
\hline Mean depth $\mathrm{m}$ & 5.2 & 1.3 & 3.8 & 2.5 & 6.3 \\
\hline Maximum amplitude & & & & & \\
\hline of regulation $\mathrm{m}$ & - & 1 & 6 & 2 & 11 \\
\hline Conductivity $\mathrm{mS} \mathrm{m}^{-1}$ & 3.4 & 3.4 & 3.8 & 4.0 & 5.7 \\
\hline Alkalinity $\mathrm{mmol} \mathrm{dm} \mathrm{dm}^{-3}$ & 0.05 & 0.04 & 0.03 & 0.24 & 0.16 \\
\hline $\mathrm{pH}$ & 6.1 & 5.9 & 5.7 & 6.7 & 5.8 \\
\hline Colour Pt mg dm $\mathrm{m}^{-3}$ & 110 & 190 & 200 & 130 & 330 \\
\hline $\operatorname{COD}(\mathrm{Mn}) \mathrm{mg} \mathrm{dm}^{-3}$ & 15 & 18 & 28 & 11 & 39 \\
\hline Total $\mathbf{P} \mu \mathrm{g} \mathrm{dm}-3$ & 16 & 22 & 53 & 38 & 190 \\
\hline Total Fe $\mu \mathrm{g} \mathrm{dm}^{-3}$ & 660 & 1300 & 1500 & 2100 & 4300 \\
\hline Total Ca $\mu \mathrm{g} \mathrm{dm}^{-3}$ & 2400 & 1900 & 2300 & 2600 & 3200 \\
\hline
\end{tabular}




\subsection{Sampling methods}

Samples were collected during the years 19801984. The fish (pike, Esox Lucius L.; perch, Perca fluviatilis L.; roach, Rutilus rutilus L.) were caught with fykes and nets and frozen immeadiately in aluminium foil and stored at $-20^{\circ} \mathrm{C}$. Fresh tissues were used for the analyses. Tissue samples were taken under the last dorsal fin immediately above the horizontal septum and a few millimeter below the skin.

The sampling of zoobenthos was performed manually from littoral areas. Most samples consisted of trichoptera larvae but some dragonfly larvae were also collected. The samples were kept in water for 4-10 hours before removing the larvae and freezing. Samples were freeze-dried under reduced pressure before analysing.

The sampling of zooplankton was carried out mainly from littoral areas using $400 \mu \mathrm{m}$ mesh plankton nets. In addition some samples were collected from pelagial areas. Some of the samples were frozen immediately in the field with solid carbon dioxide $\left(-79^{\circ} \mathrm{C}\right)$. Zooplankton samples were freeze-dried under reduced pressure.

Settleable solids (sedimentation samples) were collected in $5 \mathrm{~cm}$ (diameter) glass funnels which were placed in different sites in the lake about one meter above the bottom. The funnels were emptied at two-month intervals and samples were collected through out the year. In addition to settleable solids the funnels also gathered some zooplankton of large size. For the analyses the samples were centrifuged and air-dried.

Sediment samples were taken by crust-freeze sampling (Renberg 1981) from lakes depths. The sediment columns were cut into $1-2 \mathrm{~cm}$ layers and air-dried to constant weight.

Aquatic birds were shot and frozen in aluminium foil. Fresh tissues of the chest muscles were used for the analyses. The eggs of goldeneyes (Bucephala clangula L.) were collected from several nests and frozen and freeze-dried before determination of mercury. In the case of eggs of which the yolk and white could be separated, these were analysed separately. The shells of the eggs were not analysed.

\subsection{Analysis methods}

The analyses of mercury were performed with a Perkin Elmer Coleman MAS-50 mercury ana- lyzer. The reduction vessel was a $100 \mathrm{~cm}^{3}$ gas washing bottle and the carrier gas was nitrogen with a flow rate of $1.2 \mathrm{dm}^{3} \mathrm{~min}^{-1}$. The gas was dried with sulfuric acid. Peak heights were recorded with a Kipp and Zonen recorder.

Using this method for the determination it is possible to analyse inorganic and organic mercury from the same sample. The $\mathrm{NaOH}$ digestion procedure employed was a modification of that used by Oda and Ingle (1981). Magos (1971) reagents were used for the reduction of mercury compounds.

Reagents:

- Sodium hydroxide, $\mathrm{NaOH}$, Merck p.a., $45 \%$ $(\mathrm{w} / \mathrm{v})$ aqueous solution.

- Nitric acid, $\mathrm{HNO}_{3}$, Merck p.a., $69.6 \%$.

- Sodium chloride, $\mathrm{NaCl}$, Merck p.a., $1 \%(w / v)$ aqueous solution.

- The reductant, $10 \%(\mathrm{w} / \mathrm{v})$ tin (II) chloride $\left(\mathrm{SnCl}_{2}\right.$, Merck p.a.), 2\% (w/v) cadmium (II) chloride $\left(\mathrm{CdCl}_{2}\right.$, Merck p.a.) and $5 \%$ sulfuric acid $\left(\mathrm{H}_{2} \mathrm{SO}_{4}\right)$ in an aqueous solution. The bubbling of the reductant removed mercury that may have been present.

- n-Octanol, $\mathrm{CH}_{3}\left(\mathrm{CH}_{2}\right)_{7} \mathrm{OH}$, Merck p.a., antifoam.

- Organic mercury standard: about $310 \mathrm{mg}$ of methyl mercury (II) chloride $\left(\mathrm{CH}_{3} \mathrm{HgCl}\right.$, Merck z.a.) was dissolved in $25 \mathrm{~cm}^{3}$ of ethanol and further dilution to $250 \mathrm{~cm}^{3}$ was made with deionized water.

- Inorganic mercury standard: Coleman's 1000 $\mathrm{mg} \mathrm{Hg} \mathrm{dm}{ }^{-3}$ mercury standard was diluted to $1 \mathrm{mg} \mathrm{Hg} \mathrm{dm}{ }^{-3}$ with water.

Procedure:

A portion of $0.3-0.4 \mathrm{~g}$ wet weight or $0.1-0.2 \mathrm{~g}$ dry weight of the sample was carefully weighed in a $50 \mathrm{~cm}^{3}$ test-tube and $3 \mathrm{~cm}^{3}$ of $\mathrm{NaOH}$ was added. The test-tube was tightly capped and heated in boiling water for $15-30 \mathrm{~min}$. After cooling $3 \mathrm{~cm}^{3}$ of $\mathrm{NaCl}$ and $8 \mathrm{~cm}^{3}$ of nitric acid were added. The solution was then cooled for at least one hour (or overnight), transferred to the reduction vessel and diluted to $30 \mathrm{~cm}^{3}$ with deionized water. Two drops of n-octanol and 2 $\mathrm{cm}^{3}$ of the reductant were added. The reduction vessel was then immediately connected to the gas flow and the maximum absorbance, due to inorganic mercury ( + phenyl mercury, Campe et al. 1978, Campe et al. 1982), was recorded. After the peak had returned to the base line $9 \mathrm{~cm}^{3}$ of $\mathrm{NaOH}$ was added and again the maximum ab- 
sorbance, now due to organic mercury, was recorded. Serial amounts of the standard solutions and the reagent blank were analysed in the same way.

This method for the determination of mercury species (SEP-ALK) was compared with the method of the Research Laboratory of the National Board of Waters, in which a commonly accepted method for the determination of total mercury (TOT-ACD), involving acid digestion, oxidation with potassium permanganate and reduction with tin(II)chloride, is used. Seventyseven fish samples were analysed with these two methods (Fig. 2.) and the results of total mercury were compared using the paired t-test (Tables 2 and 3).

According to the t-test the results obtained with the TOT-ACD method were significantly higher than those obtained with the SEP-ALK method.

Earlier, Kacprzach and Chvojka (1976) carried out a similar study in which the selective method yielded the same results as the "permanganate" method when the content of mercury was below

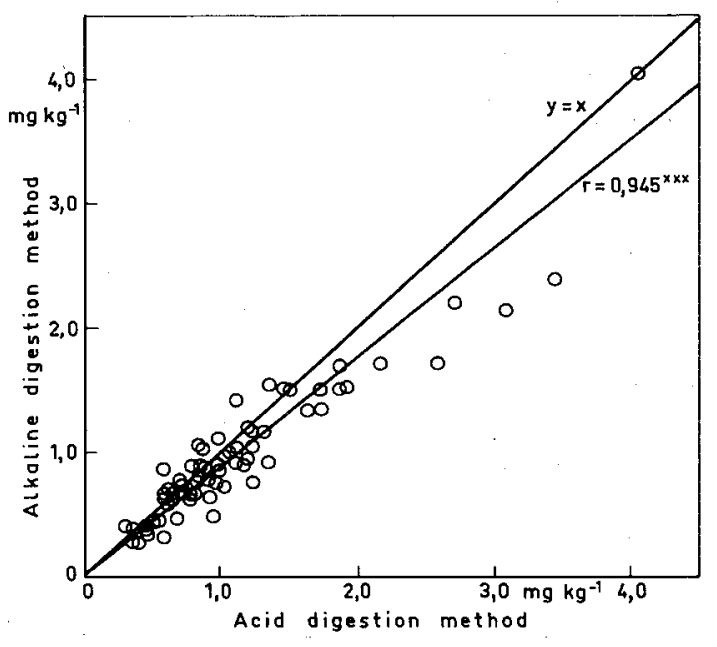

Fig. 2. Results of the determination of total mercury by the TOT-ACD (acid digestion) and SEP-ALK (alkaline digestion) methods.

Table 2. Statistical analysis of the results of total mercury obtained with the SEP-ACD methods.

\begin{tabular}{|c|c|c|c|}
\hline & SEP-ALK & & TOT-ACD \\
\hline $\begin{array}{l}\text { Mean }(\overline{\mathbf{x}}), \mathrm{mg} \mathrm{kg}^{-1} \\
\text { Standard deviation }(\mathrm{s}), \mathrm{mg} \mathrm{kg}^{-1} \\
\text { Number of cases }(\mathrm{N})\end{array}$ & $\begin{array}{r}0.992 \\
0.571 \\
77\end{array}$ & & $\begin{array}{r}1.095 \\
0.686 \\
77\end{array}$ \\
\hline $\begin{array}{l}\text { t-Test } \\
\text { Mean of the differences } \\
\text { Standard deviation of } \\
\text { the differences }\end{array}$ & $\mathrm{p}<$ & $\begin{array}{l}0.001 \\
0.10 \\
0.24\end{array}$ & \\
\hline $\begin{array}{l}\text { Regression line } \\
\text { Correlation coefficient }\end{array}$ & $\begin{aligned} \text { TOT-ACD } & =1.137 \\
r & =0.945\end{aligned}$ & SEP-ALK -0.0325 & \\
\hline
\end{tabular}

Table 3. Statistical analysis of the results below $1 \mathrm{mg} \mathrm{kg}^{-1}$ obtained with the SEP-ALK and TOT-ACD methods.

\begin{tabular}{|c|c|c|c|}
\hline & SEP-ALK & & TOT-ACD \\
\hline $\begin{array}{l}\text { Mean }(\bar{x}), \mathrm{mg} \mathrm{kg}^{-1} \\
\text { Standard deviation (s), } \mathrm{mg} \mathrm{kg}^{-1} \\
\text { Number of cases }(\mathrm{N})\end{array}$ & $\begin{array}{r}0.651 \\
0.187 \\
41\end{array}$ & & $\begin{array}{r}0.679 \\
0.187 \\
41\end{array}$ \\
\hline $\begin{array}{l}\text { t-Test } \\
\text { Mean of the differences } \\
\text { Standard deviation of } \\
\text { the differences }\end{array}$ & & $\begin{aligned} & \mathrm{p}= 0.157 \\
& 0.028 \\
& \\
& 0.13\end{aligned}$ & \\
\hline
\end{tabular}


$1 \mathrm{mg} \mathrm{kg}{ }^{-1}$. The differences between the results obtained in the present study were also found to be insignificant in the case of results below $1 \mathrm{mg}$ $\mathrm{kg}^{-1}$ (Table 3).

\section{RESULTS AND DISCUSSION 3.1 Mercury concentrations in the study areas}

The highest mercury concentrations in most organisms were found in the Kalajärvi and Kyrkösjärvi reservoirs (Fig. 3.) and the lowest concentrations in lake Seinäjärvi. However, remarkable differences between mercury concentrations in the different areas were found only in fish and aquatic birds. The contents of mercury increased considerably when ascending the food chain in all the study areas.

\section{Aquatic birds}

The highest level of total mercury was always found in fish-eating birds, the maximum concentration being $1.95 \mathrm{mg} \mathrm{kg}^{-1}$ in a black-throated diver (Gavia arctica L.) found dead in lake Pihlajavesi.

Goldeneyes had lower mercury levels than the fish-eating birds, as was found in the mercurypolluted Lake Päijänne (Särkkä et al. 1978c, Paasivirta et al. 1981b). As a rule mercury concentrations in the eggs of the goldeneyes were higher (Fig. 3.) than those in the muscle of juvenile or adult goldeneyes (Table 4.), indicating that fe-
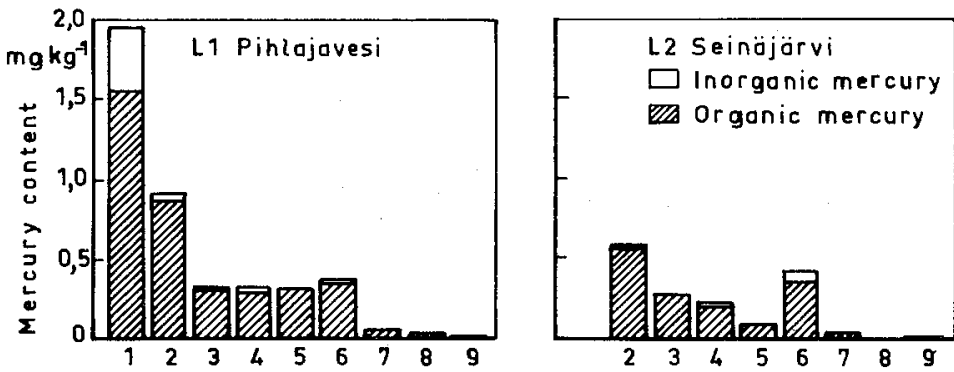

Trophic levels:

1 Fish-cating birds

2 Pike

3 Roach

4 Adult goldeneye

5 Juvenile goldeneye

6 Eggs of goldeneye

7 Benthic animals

8 Zooplankton

9 Settleable solids (sedimentation)
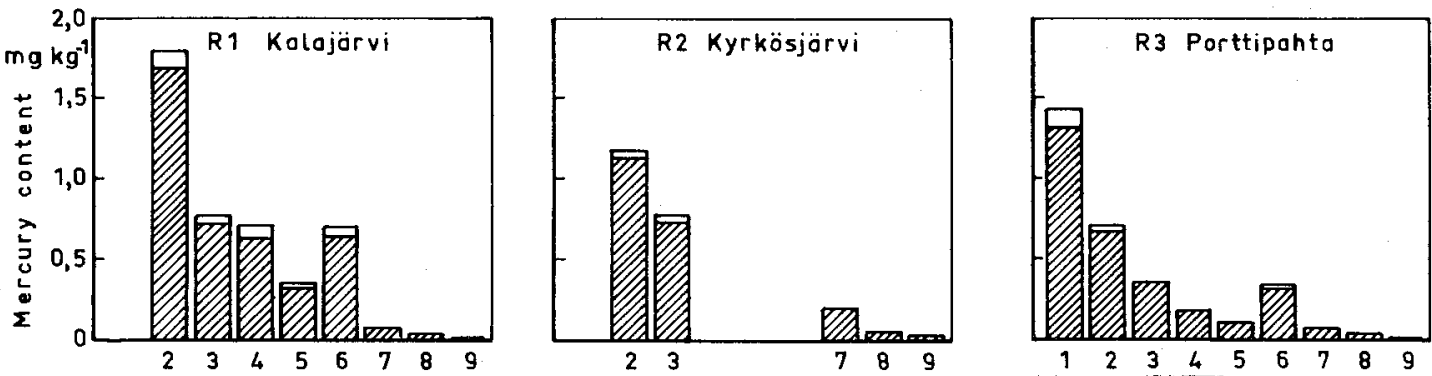

Fig. 3. Inorganic and organic mercury concentrations ( $\mathrm{mg} \mathrm{kg}^{-1}$ fresh weight) in different trophic levels at five study areas.

Table 4. Number of cases $(N)$, mean values $(\bar{x})$ and range of total mercury and organic mercury contents $\left(\mathrm{mg} \mathrm{kg}^{-1}\right)$ in fresh tissue of chest muscle of juvenile and adult goldeneyes from four areas.

\begin{tabular}{lrccrc}
\hline Area & \multicolumn{2}{c}{ Total mercury $\left(\mathrm{mg} \mathrm{kg}^{-1}\right)$} & \multicolumn{2}{c}{ Organic mercury $\left(\mathrm{mg} \mathrm{kg}^{-1}\right)$} \\
\cline { 2 - 5 } & $\mathrm{N}$ & $\overline{\mathrm{x}}$ & range & & \multicolumn{1}{c}{ range } \\
\hline L1 Pihlajavesi & 6 & 0.33 & $0.19-0.52$ & 0.30 & $0.18-0.42$ \\
L2 Seinäjärvi & 8 & 0.14 & $0.01-0.31$ & 0.13 & $0.01-0.30$ \\
R1 Kalajärvi & 10 & 0.43 & $0.15-1.06$ & 0.38 & $0.14-0.95$ \\
R3 Porttipahta & 5 & 0.11 & $0.08-0.17$ & 0.10 & $0.08-0.16$ \\
\hline
\end{tabular}


male birds excrete large quantities of mercury into the eggs.

If it is assumed that the mercury content of the muscle represents the average mercury concentration in the bird, the overall amount of mercury in goldeneyes can be calculated. The results of this calculation clearly indicate that the amount of mercury is considerably greater in juveniles in those study areas (Kalajärvi and lake Pihlajavesi) where the concentrations in adult goldeneyes are also highest (Fig. 4.). Thus, the method of total amount comparison (Paasivirta et al. 1981b) proved to be applicable to the comparison of regional differences in pollution. The mercury content in zoobenthos (trichoptera) was also significantly higher in these study areas indicating (Fig. 3) that dietary mercury intake by goldeneyes has a significant role in these areas.

\section{Fish}

The concentration of mercury in both roach and pike was considerably higher in the two young reservoirs than in the other study areas (Tables 5 and 6), exceeding $1.0 \mathrm{mg} \mathrm{kg}^{-1}$ in pike, which is the limit for edible fish laid down by the National Board of Health in Finland. In the nonregulated natural lake Pihlajavesi the mean mercury concentration of pike $\left(0.92 \mathrm{mg} \mathrm{kg}^{-1}\right.$, wet weight) was among the highest in comparison with other unpolluted Finnish lakes (Paasivirta et al. 1983, Verta et al. 1986a).

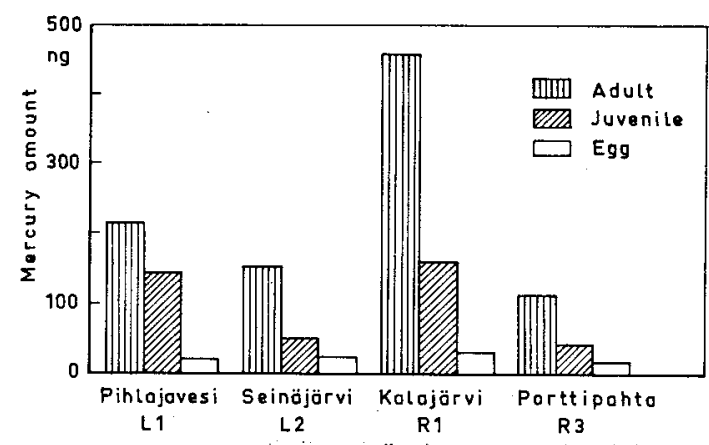

Fig. 4. The overall amount of mercury (ng) in adults $(650 \mathrm{~g})$, juveniles $(500 \mathrm{~g})$ and eggs $(50 \mathrm{~g})$ of goldeneyes from four areas.

\section{Zoobenthos}

Total mercury concentrations in zoobenthos ranged between 0.01 and $0.47 \mathrm{mg} \mathrm{kg}^{-1}$ (wet weight) in reservoirs and between 0.003 and 0.16 $\mathrm{mg} \mathrm{kg}{ }^{-1}$ in natural lakes (Table 7). The corresponding values on a dry weight basis were $0.07-$ $1.6 \mathrm{mg} \mathrm{kg}^{-1}$ and $0.02-0.62 \mathrm{mg} \mathrm{kg}^{-1}$, respectively. The values from natural lakes were in good agreement with earlier reports from uncontaminated environments (Johnels et al. 1967, Hasselrot and Göthberg 1974, Huckabee and Hildenbrand 1974, Grahn et al. 1976, Göthberg 1983).

Table 5. Number of cases $(\mathrm{N})$, mean values $(\overline{\mathrm{x}})$ and range of total mercury and organic mercury contents $\left(\mathrm{mg} \mathrm{kg}^{-1}\right)$ in fresh muscle of pike from five areas.

\begin{tabular}{|c|c|c|c|c|c|}
\hline \multirow[t]{2}{*}{ Arca } & \multicolumn{3}{|c|}{ Total mercury $\left(\mathrm{mg} \mathrm{kg}^{-1}\right)$} & \multicolumn{2}{|c|}{ Organic mercury $\left(\mathrm{mg} \mathrm{kg}^{-1}\right)$} \\
\hline & $\overline{\mathbf{N}}$ & $\overline{\mathrm{x}}$ & range & $\vec{x}$ & range \\
\hline L1 Pihlajavesi & 35 & 0.92 & $0.50-1.74$ & 0.87 & $0.47-1.59$ \\
\hline L2 Seinäjärvi & 47 & 0.60 & $0.23-1.51$ & 0.58 & $0.23-1.38$ \\
\hline R1 Kalajärvi & 70 & 1.80 & $0.85-4.06$ & 1.69 & $0.68-3.90$ \\
\hline R2 Kyrkösjärvi & 17 & 1.19 & $0.63-1.85$ & 1.14 & $0.59-1.81$ \\
\hline R3 Porttipahta & 46 & 0.70 & $0.30-1.71$ & 0.67 & $0.25-1.63$ \\
\hline
\end{tabular}

Table 6. Number of cases $(\mathrm{N})$, mean values $(\overline{\mathrm{x}})$ and range of total mercury and organic mercury contents $\left(\mathrm{mg} \mathrm{kg}^{-1}\right)$ in fresh muscle of roach from five areas.

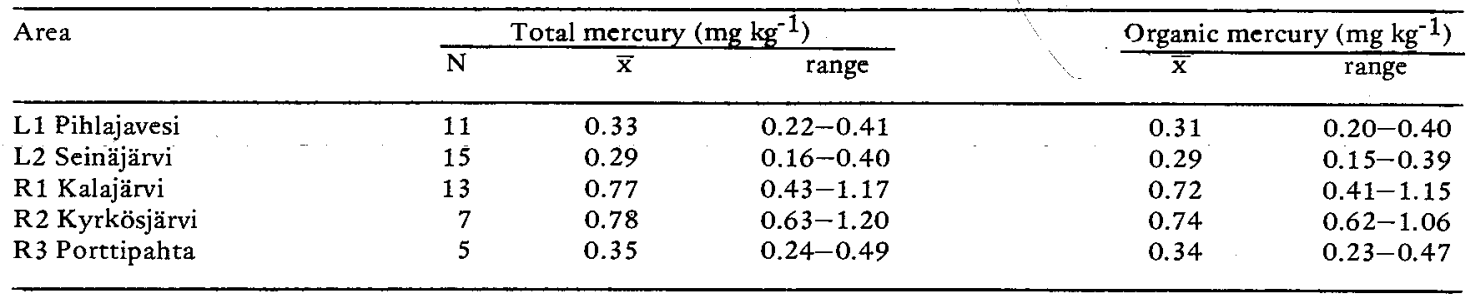


Concentrations in young reservoirs were, however, significantly higher than those in other study areas and the mean and maximum values exceeded all those reported in uncontaminated natural areas.

Using the same analytical method Verta et al. (1986a) reported for total mercury a range of $0.04-0.76 \mathrm{mg} \mathrm{kg}^{-1}$ (dry weight) which corresponds $0.009-0.114 \mathrm{mg} \mathrm{kg}^{-1}$ on a wet weight basis in zoobenthos of Finnish forest lakes.

\section{Zooplankton}

Total mercury concentrations in zooplankton ranged from 0.05 to $0.73 \mathrm{mg} \mathrm{kg}^{-1}$ (dry weight) in reservoirs and from 0.11 to $0.55 \mathrm{mg} \mathrm{kg}^{-1}$ (dry weight) in natural lakes (Table 8). The corresponding values on a wet weight basis were $0.002-0.135 \mathrm{mg} \mathrm{kg}^{-1}$ and $0.001-0.154 \mathrm{mg} \mathrm{kg}^{-1}$, respectively. Only a slight difference was found between young reservoirs and the other study areas in 1982-1983 although very high concentrations (max. $2.1 \mathrm{mg} \mathrm{kg}^{-1}$, dry weight) were found in the youngest reservoir in 1981 (Verta et al. 1986b).

Reported values from uncontaminated small forest lakes are rare. Mercury concentrations ranged from 0.03 to $0.18 \mathrm{mg} \mathrm{kg}^{-1}$ (dry weight) total mercury in one study (Grahn et al. 1976, Cajander 1980) and were less than $0.25 \mathrm{mg} \mathrm{kg}^{-1}$ (dry weight) methyl mercury in another (Hultberg and Hasselrot 1981). Verta et al. (1986a) found that the concentrations in zooplankton ranged from 0.02 to $0.55 \mathrm{mg} \mathrm{kg}^{-1}$ (dry weight) in Finnish forest lakes.

It seems possible that impounded reservoirs and brown-water lakes have higher concentrations of mercury in zooplankton than clearwater lakes since the lakes in the present study are considerably more humic than those studied by Grahn et al. (1976), Cajander (1980) and Hultberg and Hasselrot (1981). Hultberg and Hasselrot (1981) also found that water in Swedish "high level lakes", in which the concentrations of methyl mercury in zooplankton and fish were higher than in other lakes with the same $\mathrm{pH}$, usually had a high colour value.

\section{Settleable solids}

No differences were found between the mercury concentrations of settleable solids (sedimentation samples) in the study areas (Table 9). Mercury content did not correlate with the concentration of organic matter. The mean organic matter concentration (ignition loss) was $41.1 \%$.

\subsection{Correlation of mercury content of pike with weight, length and age}

Both inorganic and organic mercury concentrations in muscle of pike correlated positively

Table 7. Number of cases $(N)$, mean values $(\bar{x})$ and range of total mercury and organic mercury contents $\left(\mathrm{mg} \mathrm{kg}^{-1}\right)$ in zoobenthos (wet weight) from five areas.

\begin{tabular}{|c|c|c|c|c|c|}
\hline \multirow[t]{2}{*}{ Area } & \multicolumn{3}{|c|}{ Thotal mercury (mg kg ${ }^{-1}$ ) } & \multicolumn{2}{|c|}{ Organic mercury $\left(\mathrm{mg} \mathrm{kg}^{-1}\right)$} \\
\hline & $\mathbf{N}$ & $\overline{\mathrm{x}}$ & range & $\overline{\mathrm{x}}$ & range \\
\hline L1 Pihlajavesi & 13 & 0.055 & $0.008-0.155$ & 0.045 & $0.007-0.138$ \\
\hline L2 Seinäjärvi & 26 & 0.045 & $0.003-0.112$ & 0.040 & $0.002-0.089$ \\
\hline R1 Kalajärvi & 22 & 0.083 & $0.020-0.231$ & 0.078 & $0.010-0.221$ \\
\hline R2 Kyrkösjärvi & 12 & 0.205 & $0.022-0.472$ & 0.186 & $0.021-0.446$ \\
\hline R3 Porttipahta & 24 & 0.056 & $0.010-0.139$ & 0.047 & $0.007-0.106$ \\
\hline
\end{tabular}

Table 8 . Number of cases $(N)$, mean values $(\widetilde{x})$ and range of total mercury and organic mercury contents $\left(\mathrm{mg} \mathrm{kg}^{-1}\right)$ in zooplankton (dry weight) from five areas.

\begin{tabular}{|c|c|c|c|c|c|c|}
\hline \multirow[t]{2}{*}{ Area } & & \multicolumn{3}{|c|}{ Total mercury (mg kg $\left.{ }^{-1}\right)$} & \multicolumn{2}{|c|}{ Organic mercury (mg kg-1 } \\
\hline & & $\mathrm{N}$ & $\overline{\mathrm{x}}$ & range & $\bar{x}$ & range \\
\hline L1_Pihlajavesi & - - & 9 & 0.22 & $0.12=0.39$ & 0.19 & $0.11-0.33$ \\
\hline L2 Seinäjärvi & & 8 & 0.28 & $0.11-0.55$ & 0.22 & $0.09-0.49$ \\
\hline R1 Kalajärvi & & 8 & 0.30 & $0.13-0.73$ & 0.26 & $0.12-0.62$ \\
\hline R2 Kyrkösjärvi & & 7 & 0.42 & $0.19-0.65$ & 0.38 & $0.19-0.63$ \\
\hline R3 Porttipahta & & 26 & 0.24 & $0.05-0.43$ & 0.18 & $0.04-0.41$ \\
\hline
\end{tabular}


Table 9. Number of cases $(N)$, mean values $(\bar{x})$ and range of total mercury and organic mercury contents $\left(\mathrm{mg} \mathrm{kg}^{-1}\right)$ in settleable solids (dry weight) from five areas.

\begin{tabular}{|c|c|c|c|c|c|}
\hline \multirow[t]{2}{*}{ Area } & \multicolumn{3}{|c|}{ Total mercury $\left(\mathrm{mg} \mathrm{kg}^{-1}\right)$} & \multicolumn{2}{|c|}{ Organic mercury (mg kg-1) } \\
\hline & $\mathbf{N}$ & $\overline{\mathrm{x}}$ & range & $\bar{x}$ & range \\
\hline L1 Pihlajavesi & 14 & 0.30 & $0.11-0.49$ & 0.14 & $0.01-0.40$ \\
\hline L2 Seinäjoki & 13 & 0.22 & $0.12-0.37$ & 0.10 & $0.04-0.16$ \\
\hline R1 Kalajärvi & 12 & 0.18 & $0.06-0.38$ & 0.09 & $0.04-0.23$ \\
\hline R2 Kyrkösjärvi & 1 & 0.42 & & 0.21 & \\
\hline R 3 Porttipahta & 5 & 0.23 & $0.17-0.28$ & 0.16 & $0.14-0.19$ \\
\hline
\end{tabular}

with body weight of fish in all the areas except the Kyrkösjärvi reservoir (Fig. 5). The Kyrkösjärvi reservoir is very young and the mercury concentrations in fish are rapidly increasing (Fig. 6). The variation of weight was very limited in the samples from Kyrkösjärvi. In other areas the correlation coefficients of mercury content with age and length were of the same magnitude as those with weight. Several authors have reported similar positive size-age relationships for total mercury concentration in predatory fish (Johnels et al. 1967, Scott and Amstrong 1972, Kelly et al. 1975, Annett et al. 1975, Paasivirta et al. 1981a).

\subsection{Proportion of organic mercury of total mercury}

The proportion of organic mercury of total mercury had a range of $72.7-98.0 \%$ in individual birds, $75.5-100 \%$ in fish, $35.6-100 \%$ in zoobenthos, $45.1-100 \%$ in zooplankton and $2.4-$ $87.3 \%$ in settleable solid samples. The mean proportions for different materials were:

$\begin{array}{ll}\text { fish } & 95.1 \% \\ \text { birds } & 90.8 \% \\ \text { goldeneye eggs } & 86.4 \% \\ \text { zoobenthos } & 86.0 \% \\ \text { zooplankton } & 79.9 \% \\ \text { settleable solids } & 51.3 \%\end{array}$

The organic mercury in fish and in other biological material can be assumed to be present almost entirely as monomethyl mercury, since no other organic mercury compound has been reported (Huckabee et al. 1979). The methyl mercury fraction measured in fish is of the same magnitude as those reported earlier (Noren and Westöö 1967, Bache et al. 1971, Zitko et al. 1971, Kamps et al. 1972, Lockhart et al. 1972, Hucka- bee et al. 1974, Kacprzak and Chovjak 1976, Manthey and Berge 1980). A considerably lower fraction of methyl mercury in zoobenthos has been reported, although the range was $0-100 \%$ (Jernelöv and Lann 1971, Huckabee and Hildenbrand 1974, Cox et al. 1975, Trudel et al. 1977). The great variation of methyl mercury in zooben-
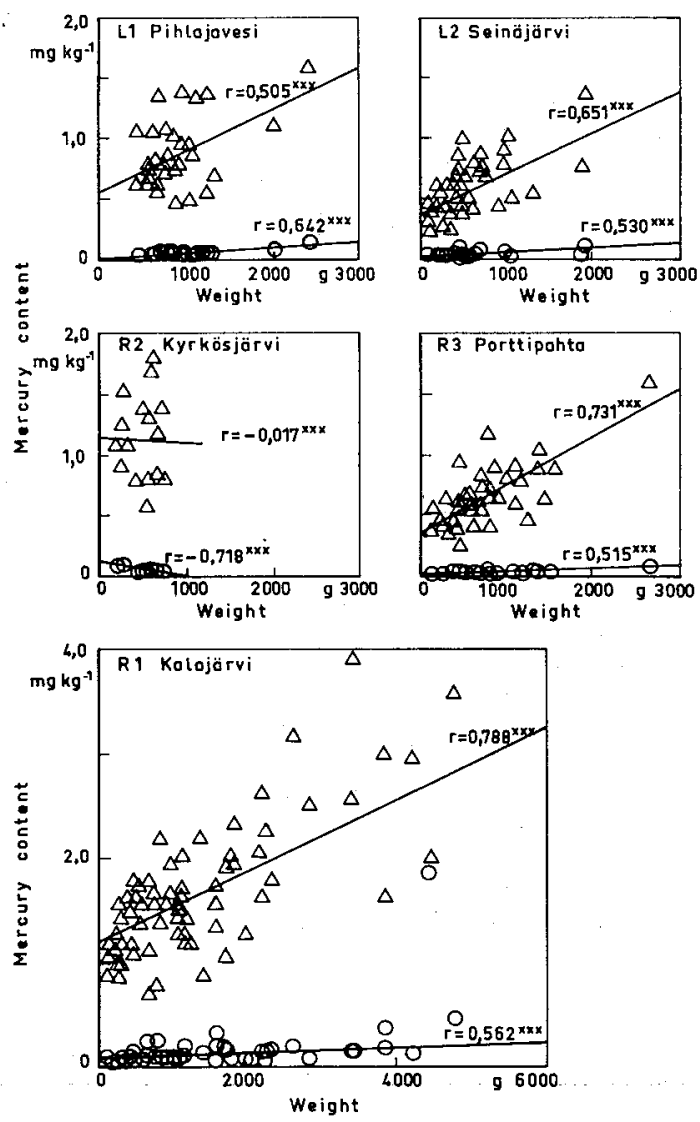

Fig. 5. Relations of organic $(\Delta)$ and inorganic $(O)$ mercury concentrations ( $\mathrm{mg} \mathrm{kg}^{-1}$ ) to body weight of fish $(\mathrm{g})$ for individual samples of pike. 


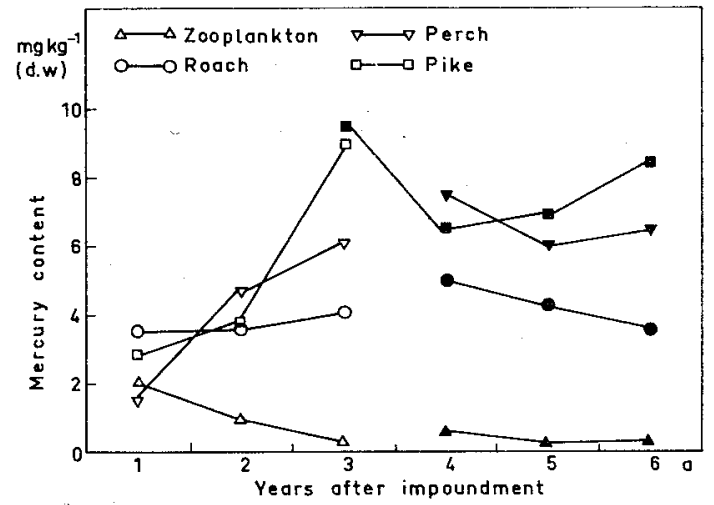

Fig. 6. Total mercury contents in the Kyrkösjärvi (R2; light spots) and Kalajärvi (R 1; dark spots) reservoirs after impoundment.

thos may be explained both by the different species and classes of zoobenthos studied and by analytical differences.

No statistical differences in the methyl mercury fraction were found between the study areas, with the exception of the Kyrkösjärvi reservoir, which had somewhat higher methyl mercury fractions in zooplankton than did the other study areas.

\subsection{The effect of the soil and humic material on mercury concentrations}

Methylated mercury is known to be produced in the sediment and water phase of aquatic environments (Westöö 1966, Jensen and Jernelöv 1969, Jernelöv 1970) and in soils (Van Faassen 1970, Yamada and Tonomura 1972). Humic substances have been found to methylate mercury abiotically (Rogers 1977, Nagase et al. 1982, Nagase et al. 1984). Furthermore, it has recently been reported that in polyhumic waters up to more than $90 \%$ of the total carbon in zooplankton may be allochthonous (Salonen and Hammar 1984).

In Kyrkösjärvi very high mercury concentrations in zooplankton (max. $2.1 \mathrm{mg} \mathrm{kg}^{-1}$, dry weight, Verta et al. 1986b) were observed during the first summer after impoundment (Fig. 6). The measured concentration is five times higher than the mean concentration found in the same area two years later, and nearly ten times that found in other areas in the present study and likewise tenfold compared to the mean concentration in a study of 35 Finnish forest lakes (Verta et al. 1986a).

Higher mercury contents in zoobenthos of the young reservoirs than in the other study areas is evident, although the difference is not as clear as in the case of zooplankton. However, it seems possible that immediatedly after impoundment large amounts of already methylated mercury, or mercury that can very easily be methylated are dissolved to the water phase and accumulated particularly into zooplankton.

It should be noted that during the first years of impoundment very low oxygen concentrations (down to $0 \%$ ) and very dark colour (up to 1000 Pt $\mathrm{mg} \mathrm{dm}^{-3}$ ) were recorded in the water of the Kyrkösjärvi reservoir. In the second winter after impoundment a mercury concentration of $40 \mathrm{ng}$ $\mathrm{dm}^{-3}$ was measured in an oxygen free water sample $1 \mathrm{~m}$ above the bottom of the Kyrkösjärvi reservoir (Verta et al. 1986b), which also indicates the dissolving of mercury from the immersed soils.

The mercury concentrations in pike in the study areas cannot be explained by the mercury concentration in sediments, water $\mathrm{pH}$ and trophic level as Håkanson (1980) has proposed (Table 10). The observed values for $1 \mathrm{~kg}$ pike exceed those calculated with the formula of Håkanson (1980) by a factor of 5-8 in impounded reservoirs and by a factor of 1.5-2 in natural lakes.

Only one thorough study of mercury contents in food chains has carried out earlier in Finland (Hattula et al. 1978, Särkkä et al. 1978 a, b, c). When comparing the results of the present study with those in lake Päijänne (Table 11), a clear difference in the accumulation pattern of mercury was observed. The mercury content in biota were of the same level or even higher in the young reservoirs than in lake Päijänne, although the concentrations in the flooded land were significantly lower than in the sediments of lake Päijänne. These data further indicate that methylation or accumulation of mercury is more effective in lakes and impoundments containing large quantitites of humic material than in clear-water lakes or lakes with inorganic mercury pollution.

\subsection{Development of mercury content in reservoirs}

In the Kyrkösjärvi reservoir the maximum concentration of mercury in zooplankton was 
Table 10. Comparison of the mercury concentrations found by determination of methyl mercury and by calculation using the formula of Häkanson (1980) in pike from five study areas.

$\mathrm{F}(\mathrm{Hg})=$ the content of methyl mercury in $1 \mathrm{~kg}$ pike in $\mathrm{mg} \mathrm{kg}^{-1}$ wet weight.

$\mathrm{Hg} 50=$ the weighted mean mercury content of surface sediments, $0-1 \mathrm{~cm}$, in $\mathrm{ng} \mathrm{kg}^{-1} \mathrm{dry}_{\text {weight. }}$

$\mathrm{pH} \quad=$ the mean $\mathrm{pH}$ of the water system.

BPI = the bioproduction index.

\begin{tabular}{lccccc}
\hline Area & $\begin{array}{c}\mathrm{Hg} 50 \\
\mathrm{ng} \mathrm{kg}\end{array}$ & $\mathrm{pH}$ & $\mathrm{BPI}$ & $\mathrm{F}(\mathrm{Hg})$ calculated \\
$\mathrm{mg} \mathrm{kg}^{-1}$ & $\begin{array}{c}\mathrm{F}(\mathrm{Hg}) \text { observed } \\
\mathrm{mg} \mathrm{kg}^{-1}\end{array}$ \\
\hline L1 Pihlajavesi & 220 & 6.1 & 4.2 & 0.61 & 0.95 \\
L2 Seinäjärvi & 100 & 5.6 & 5.2 & 0.33 & 0.71 \\
R1 Kalajärvi & 130 & 5.6 & 6.3 & 0.36 & 1.61 \\
R2 Kyrkösjärvi & 70 & 5.8 & 8 & 0.24 & 1.79 \\
R3 Porttipahta & 50 & 6.7 & 5.2 & 0.14 & 0.76 \\
\hline
\end{tabular}

Table 11. Comparison of mercury concentrations of young reservoirs (Kyrkösjärvi and Kalajärvi), natural lakes (Pihlajavesi and Seinäjärvi), and the mercury-polluted lake Päijänne. (Särkkä et al. $1978 \mathrm{a}, \mathrm{b})$. (dw = dry weight, ww $=$ wet weight).

\begin{tabular}{lccc}
\hline Trophic level & \multicolumn{3}{c}{ Mercury concentration $\left(\mathrm{mg} \mathrm{kg}^{-1}\right)$} \\
\cline { 2 - 4 } & Lake Päijänne & Young reservoirs & Natural lakes \\
\hline Sediment (dw) & 0.31 & 0.10 & 0.20 \\
Zoobenthos (ww) & 0.08 & 0.14 & 0.05 \\
Zooplankton (ww) & 0.01 & 0.04 & 0.04 \\
Roach (ww) & 0.50 & 0.78 & 0.31 \\
Pike (ww) & 1.51 & 1.50 & 0.76 \\
Goldeneye (ww) & 0.24 & 0.43 & 0.29 \\
\hline
\end{tabular}

reached during the first summer after impoundment. After this, the concentrations decreased smoothly (Fig. 6). In fish the maximum concentrations are probably reached within 3-5 years of impoundment, after which the concentrations might be expected to decrease slightly because of the smaller load of mercury from the soil. However, in the Kalajärvi reservoir the mercury concentration in pike again increased 5-6 years from impoundment ( $F$ ig. 6 ). This may be a consequence of the fact that the pikes are forced to change their main food source from invertebrates to fish. In many reservoirs it has been found that pikes use zoobenthos as the main food source at least for part of the year (Bodaly and Lesack 1984, Koskenniemi 1984 pers. comm.). According to several studies the maximum of the total biomass of zoobenthos is reached within $1-5$ years of impoundment (Nursall 1952, Petr 1969, 1972, Jankovic 1972, Paterson and Fernando 1970, Armitage 1977).

\section{CONCLUSION}

The analysis results are consistent with the assumption that humic substances transfer mercury from soil/sediment to the water phase and further to biota mainly in the form of organic mercury.

\section{ACKNOWLEDGEMENT}

We are gratefull to the Foundation for Research on Natural Resources in Finland and the National Boards of Waters for financial support. 


\section{TIIVISTELMÄ}

Elohopean rikastumista ravintoketjuun tutkittiin kolmessa tekojärvessä ja kahdessa luonnonjärvessä vuosina 1980-1984 analysoimalla epäorgaanisen ja orgaanisen (metyyli) elohopean pitoisuuksia ravintoketjun eri osissa. Tutkitut trofiatasot olivat sedimentoituva kiintoaines, eläinplankton, pohjaeläimet, telkän munat, telkän poikanen, aikuinen telkkä, särki, hauki ja kaloja syövät linnut.

Nuorissa tekojärvissä (Kalajärvi ja Kyrkösjärvi) todettiin yleensä kaikilla trofiatasoilla suurimmat elohopeapitoisuudet kuin luonnonjärvissä (Seinäjärvi, Pihlajavesi) tai tutkitussa vanhassa tekojärvessä (Porttipahta). Sedimentoituvassa kiintoaineessa ei havaittu eroja eri alueiden välillä.

Sekä epäorgaaninen että metyylielohopea korreloivat yleensä positiivisesti hauen painon ja pituuden kanssa. Poikkeuksena oli nuorin Kyrkösjärven tekojärvi, jossa pitoisuudet kalastossa olivat nousussa tutkimusjakson aikana.

Metyylielohopean osuus kokonaiselohopeasta oli keskimäärin kaloissa 95,1\%, linnuissa 90,8\%, lintujen munissa $86,4 \%$, pohjaeläimissä $86,0 \%$, eläinplanktonissa $79,9 \%$ ja laskeutuvassa kiintoaineessa 51,3\%. Metyylielohopean prosenttiosuudessa ei esiintynyt merkittäviä eroja eri tutkimusalueiden välillä.

Elohopeapitoisuuksien kehittyminen nuorten tekojärvien eliöstössä ja vedessä viittasivat siihen, että välittömästi tekojärven rakentamisen jälkeen suuri määrä jo metyloitunutta tai nopeasti metyloituvaa elohopeaa liukenee maaperästä veteen ja rikastuu ensi vaiheessa erityisesti eläinplanktoniin.

Vertailu kirjallisuudessa esitettyyn malliin ja Päijänteen eliöstön elohopeapitoisuuksiin viittasi siihen, että elohopean metyloituminen tai rikastuminen on tehokasta nuorissa tekojärvissä. Syyksi esitettiin humusyhdisteiden toimimista elohopean välittäjinä maaperästä veteen ja eliöstöön.

\section{REFERENCES}

Abernathy, A.R. \& Cumbie, P.M. 1977. Mercury accumulation by largemouth bass (Micropterus salmoides) in recently impounded reservoirs. Bull. Contam. Environ. Toxicol. 17: 595-602.
Alfthan, G., Järvinen, O., Pikkarainen, J. \& Verta, M. 1983. Mercury and artificial lakes in Northern Finland possible ecological and health consequences. Nordic Council Arct. Med. Res. Rep. No. 35: 77-81.

Annett, C.S., D'Itri, F.M., Ford, J.R. \& Prince, H.H. 1975. Mercury in fish and waterflow from Ball Lake, Ontario. J. Environ. Qual. 4: 219-222.

Armitage, P. 1977. Development of the macro-invertebrate fauna of cow green reservoirs (Upper

Teesdale) in the first five years of its existence. Freshwater Biol. 7:441-454.

Bache, C.A., Gutenmann, W.H. \& Lisk, D.J. 1971. Residues of total mercury and methylmercuric salts in lake trout as a function of age. Science 172: 951952.

Björklund, I. 1982. Beskriving av regionala genomsnitthalter av kvicksilver hos gädda inom Sverige. (On the regional mean concentrations of mercury in pike in Sweden.) Statens Naturvärds Verk. 1982-06-24. Mimeographed Report $20 \mathrm{p}$.

Bodaly, R.A. \& Hecky R.E. 1979. Post-impoundment increases in fish mercury levels in the Southern Indian Lake reservoir, Manitoba. Can. Fish. Mar. Serv. MS Rep. 1531,15 p.

Bodaly, R.A. \& Lesack, L.F.W. 1984. Responce of a boreal northern pike (Esox Lucius) population to lake impoundment, Wupaw Bay, Southern Indian Lake. Manitoba. Can. J. Fish. Aquat. Science 41: $706-714$.

Cajander, V-R. 1980. Elohopean esiintyminen eläinplanktonissa ja sestonissa Kokemäenjoessa klooritehtaan vaikutusalueella. (Mercury in seston and zooplankton in river Kokemäenjoki affected by a chlor-alkali plant.) Ympäristö ja Terveys 11: 678682.

Campe, A., Velghe, N. \& Claeys, A. 1978. Determination of inorganic, phenyl and total mercury in urine. Atom. Abst. Newsl. 17: 100-103.

Campe, A., Velghe, N. \& Claeys, A. 1982. Determination of inorganic, phenyl and total mercury in hair. Atom. Spectr. 3: 122-125.

Cox, J.A., Carnahan, J., DiNunzio, J., McCoy, J. \& Meister, J. 1979. Source of mercury in fish in new impoundments. Bull. Environ. Contam. Toxicol. 23: 779-783.

Cox, M.F., Holm, H.W., Kania, H.J. \& Knight, R.L. 1975. Methylmercury and total mercury in selected stream biota. In: D.D. Hemphill (Ed.), Trace Substances in Environmental Health, IX, Univ. Mo. Columbia, Mo. June 10-12, pp. 151-155.

Grahn, O. Hultberg, H. \& Jernelöv, A. 1976. Accumulation of mercury in different trophic levels - a general research of three west-swedish lakes. (Swedish). Institutet för vatten och luftvảrdsforskning. B292. Stockholm.

Göthberg, I. 1983. Intensive fishing - a way to reduce the mercury level in fish. Ambio 12: 259-261.

Hasselrot, T.B. \& Göthberg, A. 1974. The ways of transport of mercury to fish. In: Proc. Int. Conf. Transp. Persist. Chem. Aquat. Ecosyst. Ottawa, Can. May 1-3, Sect. III, pp. 37-47.

Hattula, M-L., Särkkä, J., J-anatuinen,-J., Paasivirta, J. \& Roos, A. 1978. Total mercury and methyl mercury contents in fish from Lake Päijänne. Environ. Pollut. 17: 19-29.

Hildenbrand, S.C., Andren, A.W. \& Huckabee, J.W. 
1976. Distribution and bioaccumulation of mercury in biotic and abiotic compartments of a contaminated river-reservoir system. In: R.W. Andrew, P.V. Hodson and D.E. Konasewich (Eds.), Toxicity to Biota of Metal Forms in Natural Water. Int. Jt, Comm. Great Lakes Res., Windsor, Ont., pp. 211232.

Huckabee, J.W. \& Feldman, C. \& Talmi, Y. 1974. Mercury concentrations in fish from the Great Smoky Mountains National park. Anal. Chim. Acta 70:4147.

Huckabee, J.W. \& Hildenbrand, S.G. 1974. Background concentrations of mercury and methylmercury in unpolluted freshwater environments. In: Prim. Cong. Int. Merc., Barcelona, Spain, May 6-10, 1974, pp. 214-224.

Huckabee, J.W., Elwood, J.W. \& Hildenbrand, S.G. 1979. Accumulation of mercury in freshwater biota. In: Nriagu, J.O. (ed), The biogeochemistry of mercury in the environment: 277-302. Elsevier, Amsterdam.

Hultberg, H. \& Hasselrot, B. 1981. Mercury in ecossystem. (Swedish). K.H.M. information 04: 33-55.

Hakanson, L. 1980. The quantitative impact of $\mathrm{pH}$, bioproduction and $\mathrm{Hg}$-contamination on the $\mathrm{Hg}$-content of fish (pike). Environ. Poll. (Series B) $1:$ 285-304.

Jankovic, M. 1972. Die Entwicklung der Bodenfauna in der Gebirgsstanbecken. Verh. Int. Ver. Limnol. 18: $813-817$.

Jensen, S. \& Jernelöv, A. 1969. Biological methylation of mercury in aquatic organisms. Nature 223: 753754.

Jernelöv, A. 1970. Release of methylmercury from sediments with layers containing inorganic mercury at different depths. Limnol. Oceanogr. 15:958-960.

Jernelöv, A. \& Lann, H. 1971. Mercury accumulation in food chains. Oikos 22: 403-406.

Johnels, A.G., Westermark, T., Berg, W., Persson, P.I. \& Sjöstrand, B. 1967. Pike (Esox Lucius L.) and some other aquatic organisms in Sweden as indicators of mercury contamination in the environment. Oikos 18: 323-333.

Kacprzak, J.L. \& Chvojka, R. 1976. Determination of methyl mercury in fish by flameless atomic absorbtion spectroscopy and comparison with an acid digestion method for total mercury. Journal of the AOAC 59: 153-157.

Kamps, L.R., Carr, R. \& Miller, H. 1972. Total mercurymonomethylmercury content of several species of fish. Bull. Environ. Contam. Toxicol. 8: 273-279.

Kelly, T.M., Jones, J.D. \& Smith, G.R. 1975. Historical changes in mercury contamination in Michigan walleyes (Stizostedion vitreum). J. Fish. Res. Board Can. 32: 1745-1754.

Lockhart, W.L., Uthe, J.F., Kenney, A.R. \& Mehrle, P.M. 1972. Methylmercury in northern pike (Esox lucius): distribution, elimination, and some biochemical characteristics of contaminated fish. J. Fish. Res. Board Can. 29: 1519-1523.

Lodenius, M., Seppänen, A. \& Herranen, M. 1981. Accumulation of mercury in fish and man from reservoirs in Northern Finland. Water, Air and Soil_Pollution 19: 237-246.

Magos, L. 1971. Selective atomic-absorbtion determination of inorganic mercury and methylmercury in undigested biological samples. Analyst 96: 847-853.

Manthey, G. \& Berge, H. 1980. Methode zur differen- zierten Bestimmung von anorganisch und organisch gebundenem Quecksilber in Lebensmitteln, Wasser und biologischen Materialien. Wasser und biologischen Materialien. Die Nahrung 24: 413-421.

Meister, J.F., DiNunzio, J. \& Cox, J.A. 1979. Source and level of mercury in a new impoundment. Water Techn. Qual. 71: 574-576.

Nagase, H., Ose, Y., Sato, T. \& Ishikawa, T. 1982. Methylation of mercury by humic substances in an aquatic environment. The Science of Total Environment 24: 133-142.

Nagase, H., Ose, Y., Sato, T. \& Ishikawa, T. 1984. Mercury methylation by compounds in humic substances. The Science of Total Environment 32:147156.

Noren, K. \& Westöö G. 1967. Mctylkvicksilver i fisk. (Methyl mercury in fish.) Vär Föda 19:13-17.

Nursall, J. 1952. The early development of a bottom fauna in a new power reservoirs in the Rocky Mountains of Alberta. Can. J. Zool. 30: 387-409.

Oda, C.E. \& Ingle, J.D.Jr. 1981. Speciation of mercury by cold vapor atomic absorption spectrometry with selective reduction. Anal. Chem. 53: 2305-2309.

Paasivirta, J., Särkkä, J., Aho, M., Surma-Aho, K., Tarhanen, J. \& Roos, A. 1981a. Recent trends of biocides in pikes of the lake Päijänne. Chemosphere 10 : $405-414$

Paasivirta, J., Särkkä, J., Pellinen, J. \& Humppi, T. $1981 \mathrm{~b}$. Biocides in eggs of aquatic birds. Completion of a food chain enrichment study for DDT, PCB and Hg. Chemosphere 10: 787-794.

Paasivirta, J., Särkkä, J., Surma-Aho, K., Humppi, T., Kuokkanen, T. \& Martinen, M. 1983. Food chain enrichment of organochlorine compounds and mercury in clean and polluted lakes of Finland. Chemosphere $12 ; 239-252$.

Paterson, C. \& Fernando, C. 1970. Benthic fauna colonization of a new reservoir with particular reference to the Chrironomidae. J. Fish. Res. Board Can. 27: $213-232$.

Petr, T. 1969. Development of bottom fauna in the man-made Volta Lake in Ghana. Verh. Int. Ver. Limnol. $171: 273-282$.

Petr, T. 1972. Benthic fauna of a tropical man-made lake (Volta Lake, Ghana 1965-1968). Arc. Hydrobio. 70: 484-533.

Potter, L., Kidd, D. \& Standiford, D. 1975. Mercury levels in Lake Powell. Environm. Sci. Technol. 9, 1: 41-36.

Renberg, I. 1981. Improved methods for sampling, photographing and varve-counting of varved lake sediments. Boreas 10: 255-258.

Rogers, R.D. 1977. A biological methylation of mercury in soil. J. Environ. Qual. 6:463-467.

Salonen, K. \& Hammar, T. 1984. Importance of allochtonous organic matter in the nutrition of zooplankton of humic lakes. Nordisk Limnologsymposium, Fagerfjell, 3.-4. april 1984.

Scott, D.P. \& Amstrong, F.A. 1972. Mercury concentration in relation to size in several species of freshwater fishes from Manitoba and North-Western Ontario. J. Fish. Res. Board Can. 39: 1685-1690.

Särkkä, J., Hattula, M-L., Janatuinen, J. \& Paasivirta, J. 1978a. Mercury in sediments of lake Päijänne, Finland. Bull. Environ. Contam. Toxicol. 20:332-339.

Särkkä, J., Hattula, M-L., Paasivirta, J. \& Janatuinen, J. 1978 b. Mercury and chlorinated hydrocarbons in the 
food chain of lake Päijänne, Finland. Holarctic Ecology 1 : 326-332.

Särkkä, J., Hattula, M-L., Janatuinen, J., Paasivirta, J. \& Palokangas, R. 1978c. Chlorinated hydrocarbons and mercury in birds of Lake Päijänne, Finland. 1972-74. Pestic. Monit. J. 12: 26-35.

Trudel, B.K., deFreitas, A.S.W. \& Miller, D.R. 1977. Mercury dynamics of the aquatic invertebrate community in the Ottawa River study area. In: Distribution and Transport of Pollutants in Flowing Water Ecosystems, Final Rep., Ottawa River Project, National Reserarch Countill of Canada, Ottawa, Ca., IKA CR6.

Van Faassen, H.G. 1976. Methylation of mercury compounds in soil, sediment and sewage-sludge samples. Plant Soil 44: 505-509.

Verta, M. 1981. Tekoaltaiden kalojen elohopeapitoisuudet vuonna 1980 ja arvio pitoisuuksien kehittymisestä. (Mercury concentrations in fish in Finnish reservoirs in 1980 and prognosis future trends.) National Board of Waters, Finland. Report 212:45-73.

Verta, M., Mannio, J., Rekolainen, S. \& Surma-Aho, K. 1986a. The origin and level of mercury in Finnish forest lakes. Publications of the Water Research Institute, National Board of Waters, Finland. No. 65 : $\mathbf{x x x}-\mathbf{x x x}$

Verta, M., Rekolainen, S. \& Kinnunen, K. 1986b. Causes of increased fish mercury levels in Finnish reservoirs. Publications of the Water Research Institute, National Board of Waters, Finland. No. 65: $\mathrm{xxx}-\mathrm{xxx}$.

Westöö, G. 1966. Determination of methyl mercury compounds in foodstuffs I: Methyl mercury compounds in fish, identification and determination. Acta Chem. Scand. 20: 2131-2137.

Yamada, M. \& Tonomura, K. 1972. Formation of methylmercury compounds from inorganic mercury by Clostridium cochlearium. J. Ferment. Technol. 50: 159-16́6.

Zitko, V., Finlayson, B.J., Wildish, D.J., Anderson, J.M. \& Kohler, A.C. 1971. Methylmercury in freshwater and marine fishes in New Brunswick, in the Bay of Fundy, and on the Nova Scotia Banks. J. Fish. Res. Board Can. 28: 1285-1291. 